\title{
Hubungan Keteladanan Orang Tua dengan Perkembangan Nilai Moral Anak Usia Dini
}

\author{
Wuryaningsih ${ }^{1 凶}$, Iis Prasetyo ${ }^{1}$ \\ Pendidikan Anak Usia Dini, Universitas Negri Yogyakarta, Indonesia(1) \\ DOI: $10.31004 /$ obsesi.v6i4.2330
}

\begin{abstract}
Abstrak
Peran orang tua dalam pendidikan moral anak sangat besar, karena perilaku orang tua akan menjadi teladan bagi anak, terutama bagi anaknya yang masih berusia dini. Penelitian ini bertujuan untuk mengetahui hubungan keteladanan orang tua dengan perkembangan nilai moral anak. Jenis penelitian adalah kuantitatif. Teknik pengambilan sampel menggunakan total sampling, dan jumlah sampel penelitian adalah 109 anak (orang tua). Teknik pengumpulan data menggunakan kuesioner. Teknik analsiis data menggunakan korelasi Spearman Rho. Hasil penelitian menyimpulkan bahwa keteladanan orang tua dengan perkembangan nilai moral anak memiliki hubungan yang kuat dan signifikan. Artinya, semakin sering orang tua memberikan perilaku keteladanan kepada anaknya, maka perkembangan nilai moral anak semakin meningkat. Oleh karena itu, dalam mendidik anaknya, orang tua tidak hanya cukup dengan perintah atau ucapan saja, tetapi harus memberikan contoh perilaku yang baik bagi anaknya, dan dapat dijadikan figur yang pantas diteladani.
\end{abstract}

Kata kunci: keteladanan orang tua; nilai moral anak; anak usia dini

\begin{abstract}
The role of parents in the moral education of children is very large, because the behavior of parents will be an example for children, especially for their children who are still at an early age. This study aims to determine the relationship between parental example and the development of children's moral values. This type of research is quantitative. The sampling technique used was total sampling, and the number of research samples was 109 children (parents). Data collection techniques using a questionnaire. The data analysis technique uses Spearman Rho correlation. The results of the study concluded that the example of parents with the development of children's moral values has a strong and significant relationship. That is, the more often parents provide exemplary behavior to their children, the development of children's moral values will increase. Therefore, in educating their children, parents are not only enough with orders or words, but must set an example of good behavior for their children, and can be used as role models.
\end{abstract}

Keywords: parental example; children's moral values; early childhood

Copyright (c) 2022 Wuryaningsih, Iis Prasetyo.

$\triangle$ Corresponding author :

Email Address : wuryaningsih.tkpsumber@gmail.com (Yogyakarta, Indonesia)

Received 25 November 2021, Accepted 18 February 2022, Published 20 February 2022 


\section{PENDAHULUAN}

Berdasarkan pengamatan dan wawancara dengan guru maupun orang tua siswa di TK/RA ABA Bero I, Bero III dan Bero IV diperolah informasi bahwa: (1) Ada orang tua seringkali tidak memiliki waktu untuk mendampingi anak, karena kesibukan bekerja, sehingga anak kurang mendapat perhatian dan bimbingan; (2) Ada orang tua seringkali memanjakan anak dengan menuruti kemauan anak dan kurang melakukan kontrol terhadap perilaku anak, sehingga dapat membuat anak memiliki karakter atau moral yang tidak diinginkan; (3) Ada orang tua dalam mendidik anaknya masih menggunakan pola-pola yang kurang sesuai dengan karakter anak, dan tidak memberikan contoh teladan yang baik kepada anak-anaknya, orang tua tidak berperilaku yang baik di hadapan anak, sehingga anak akan meniru perilaku orang tua tersebut; (4) Ada orang tua kadang kurang kontrol terhadap anaknya yang suka bermain handphone atau komputer saat mengakses internet atau game online, sehingga hal ini dapat mempengaruhi perkembangan moral anak.

Perkembangan anak usia dini terbagi dalam tiga tahapan, yaitu masa bayi lahir sampai 12 bulan, masa toddler (batita) usia 1-3 tahun, masa prasekolah usia 3-6 tahun, masa kelas awal SD 6-8 tahun (Hartoyo, 2004 dalam Suhono \& Utama, 2017). Perkembangan anak usia dini mengalami perkembangan dalam memproduksi vokal suara, terutama pada umur 6 bulan. Pertumbuhan dan perkembangan anak usia dini perlu diarahkan pada peletakan dasar-dasar yang tepat bagi pertumbuhan dan perkembangan manusia seutuhnya, yaitu pertumbuhan dan perkembangan fisik, daya pikir, daya cipta, sosial emosional, bahasa dan komunikasi yang seimbang sebagai dasar pembentukan pribadi yang utuh (Hartoyo, 2004 dalam Suhono \& Utama, 2017). Thomas Lickona (2010) dalam Ramdhani et al. (2019) menjelaskan bahwa pendidikan karakter merupakan kebutuhan pokok dalam menciptakan manusia yang memiliki kepribadian dan perilaku yang baik.

Pendidikan karakter adalah usaha untuk membangun peserta didik menjadi manusia seutuhnya yang memiliki kecerdasan emosional dan spiritual sehingga mampu bertindak dan mengambil keputusan secara bijak berdasarkan nilai-nilai etika inti yaitu antara lain rasa hormat, peduli, jujur, toleransi dan berbagi. Towoliu \& Hartati (2021) menemukan bahwa perkembangan nilai agama dan moral anak terlihat dari perilaku rasa hormat, tanggung jawab, kejujuran, keadilan, toleransi, kebijaksanaan, disiplin diri, tolong menolong, peduli sesame, kerja sama, keberanian, dan demokratis.

Perkembangan kepribadian dan pembentukan budi pekerti anak usia dini sangat dipengaruhi oleh pola asuh dan keteladanan yang diterapkan oleh orang tuanya. Pola asuh dan keteladanan merupakan salah satu kegiatan yang menjadi kewajiban orang tua jika telah memiliki buah hati atau anak dalam asuhannya. Pengasuhan oleh orang tua kepada anak akan menjadi penentu kehidupan anak selanjutnya. Artinya, pola asuh dan keteladanan akan menentukan kesiapan anak untuk dapat menjalani kehidupannya secara mandiri (Sutanto \& Andriyani, 2019).

Menurut Helmawati (2014) dalam Ulfah (2020) keluarga adalah tempat pertama bagi anak-anak belajar, dalam keluarga anak belajar tentang keyakinan, sifat-sifat mulia, komunikasi, interaksi sosial serta ketrampilan dalam hidup. Penelitian (Purnama \& Hidayati, 2020) menemukan bahwa indikator-indikator pengasuhan anak dapat direduksi dari data inti aspek-aspek pengasuhan yaitu asuh, asih, dan asah. Hasil penelitian Mukarromah et al. (2021) menyimpulkan bahwa gaya pengasuhan dan pengasuhan dari keluarga khususnya orang tua memiliki keterkaitan dengan perkembangan moral anak.

Gaya pengasuhan orangtua pada anak memiliki pengaruh terhadap perkembangan anak, khususnya dengan kecerdasan moral (Sofia et al., 2021). Hasil penelitian Jeti et al. (2021) menyimpulkan bahwa keluarga memiliki peranan penting dalam menanamkan nilai-nilai ini sebagai dasar pendidikan karakter melalui pembiasaan dan keteladanan sejak usia dini dalam kehidupan sehari-hari yaitu dengan membiasakan dan mencotohkan perilaku saling menyayangi, menghormati antara sesama, saling menjaga martabat, saling melindungi, 
bekerjasama dan berempati. Penerapan nilai-nilai ini dapat membentuk anak menjadi pribadi yang berkarakter.

Peran orang tua dan perlakuannya akan berpengaruh besar pada pembentukan karakter mandiri pada setiap individu sejak usia dini, parenting style atau yang sering disebut pola asuh adalah gaya berhubungan/berinteraksi yang dilakukan orangtua terhadap anak, pada umumnya ada tiga, yang pertama yaitu otoriter adalah perilaku orangtua yang serba mengatur aktivitas anak, aturan yang dibuat oleh orangtua harus sepenuhnya ditaati oleh anak. Pola asuh kedua demokratis, yaitu hubungan orangtua dengan anak yang memberikan dorongan serta motivasi kepada apa yang menjadi harapan anaknya serta adanya demokrasi dan kontrol yang tidak kaku mengenai aturan yang dibuat. Ketiga adalah pola asuh permisif yaitu perlakuan orangtua yang memberikan kebebasan penuh pada aktrivitas anak, tidak adanya kontrol dan aturan dalam keluarga.

Begitu penting dan berartinya pola asuh dan keteladanan orang tua terhadap anak, sampai-sampai Rohner dalam Wibowo (2017) menyimpulkan bahwa pengalaman masa kecil seseorang sangat mempengaruhi perkembangan kepribadiannya kelak termasuk karakter atau kecerdasaan emosinya. Penelitian yang menggunakan teori PAR (parental acceptance-rejection theory) iji juga menyimpulkan bahwa pola asuh orang tua, baik yang menerima (acceptance) atau yang menolak (rejection) anaknya, akan mempengaruhi perkembangan emosi, perilaku, sosial kognitif, dan kesehatan fungsi psikologisnya ketika dewasa kelak. Berkaitan dengan keteladanan orang tua dan pengaruhnya terhadap perkembangan kepribadian anak, (Wibowo, 2017) menjelaskan bahwa keluarga merupakan wahana yang pertama dan utama bagi keberhasilan pendidikan karakter anak.

Karakteristik anak cenderung meniru apa yang dilihat, didengar, dirasa, dialami, maka karakter mereka akan terbentuk sesuai dengan pola asuh orang tua tersebut. Dengan kata lain anak akan belajar apa saja termasuk karakter, melalui pola asuh yang dilakukan orang tua mereka. Dengan demikian dapat disimpulkan bahwa model pola asuh yang diterapkan oleh orang tua terhadap anaknya akan menentukan keberhasilan pendidikan karakter mereka dalam keluarga (Wibowo, 2017). Selain itu, perlu dipahami bahwa setiap anak memiliki karakteristik yang khas dan unik serta tidak bisa disetarakan dengan orang dewasa. Untuk itu, orang tua memiliki kewajiban untuk memberikan perhatian dan didikan dalam proses tumbuh kembang anak, baik secara jasmani maupun rohani (Amin et al., 2021).

Faktor yang dianggap berpengaruh terhadap perkembangan kepribadian anak dan pembentukan karakter budi pekerti anak usia dini adalah keteladalan orang tua. Keteladanan orang tua sangat penting untuk diperhatikan dalam membimbing dan mendidik anakanaknya. keberadaannya merupakan bagian yang integral dalam proses pendidikan dengan tujuan untuk membekali anak dalam memecahkan segala masalah-masalah kehidupan yang dihadapinya, baik pribadi, kelompok atau sekolah, agar terbentuk pribadi yang berakhlak mulia, sesuai dengan yang dicita-citakannya, yakni menjadi anak yang berbakti kepada orang tua, agama, bangsa dan Negara (Suhono \& Utama, 2017).

Hasil penelitian (Putri et al., 2020) menyimpulkan bahwa keterlibatan orangtua yang tinggi merupakan standar bagi pengaturan diri anak dalam menampilkan perilaku yang diharapkan sesuai tumbuh kembang anak. Menurut Candra et al. (2013) dalam Kurniati et al. (2021) menyatakan bahwa pengasuhan orang tua terhadap anaknya dapat berpengaruh terhadap pembentukan karakter dan perilaku anak itu sendiri.

Menurut Juliana Langowuyo (2011) dalam Wibowo (2017) dijelaskan bahwa pendidikan karakter sebaiknya harus di mulai sejak anak usia dini. Adapun pihak yang paling bertanggung jawab untuk mendidik, mengasuh dan membesarkan anak-anak menjadi generasi yang tangguh adalah orang tua. Mereka merupakan orang yang paling dekat dengan anak sehingga kebiasaan dan segala tingkah laku yang terbentuk dalam keluarga menjadi contoh dan dengan mudah ditiru anak.

Berdasarkan pendapat Juliana tersebut, maka dapat disimpulkan bahwa keteladanan orang tua adalah faktor utama keberhasilan pendidikan karakter di dalam keluarga. "Air 
cucuran atap , jatuhnya kepelimbahan juga" demikian kata pribahasa yang erat kaitannya dengan teladan orang tua atas anak. Menurut pribahasa itu, tabiat, perilaku atau apa saja dari orang tua akan menurun atau diikuti oleh anaknya. Pribahasa yang senada adalah: "buah jatuh tak jauh dari pohonnya." Selain itu, banyak penelitian psikologi yang mengungkap bahwa sebgian besar yang anak-anak pelajari tidak berasal dari apa yang orang tua katakan ketika mengajar anaknya, namun sebagian besar ank-anak belajar dari teladan orang tuanya (Wibowo, 2017).

Keteladanan orang tua merupakan bagian terpenting dalam membentuk karakter anak, karakter keluarga. Karena waktu kebersamaan Ayah/ibu dengan anak lebih banyak.Sebagai orang tua kita bisa memiliki multi fungsi bagi anakanak kita. Adakalanya kita harus menjadi seorang motivator ulung, disaat yang lain kita dituntut untuk mampu menjadi seorang dokter, untuk menganalisa dan mengobati tingkah anak sesuai dengan dosisnya, kita juga perlu menjadi komunikator yang bisa menjembatani permasalahan anakanak kita. Didikan orang tua merupakan faktor penting dalam kehidupan manusia, karena pendidikan mempunyai peranan yang sangat esensial dalam membina martabat manusia, memelihara dan mengembangkan nilai kebudayaannya(Kabiba et al., 2017).

\section{METODOLOGI}

Pendekatan yang digunakan dalam penelitian adalah penelitian kuantitatif, karena bertujuan untuk menganalisis hubungan antara keteladanan orang tua dengan perkembangan nilai moral anak, dengan analisis statistik untuk membuktikan hipotesis yang telah dirumuskan. Desain penelitian digambarkan pada bagan gambar 1.

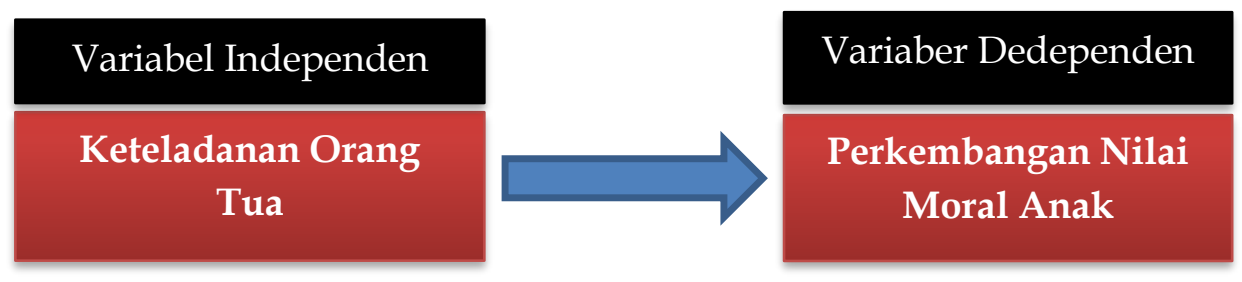

Gambar 1 Desain Penelitian

Tempat penelitian di Kecamatan Trucuk Kabupaten Klaten, dan waktu penelitian dilakukan pada bulan Oktober-November 2021. Jumlah populasi penelitian adalah semua siswa TK/RA ABA Bero I, Bero III dan Bero IV yang berjumlah 109 anak. Sampel ditetapkan dengan teknik total sampling, yaitu semua siswa yang berjumlah 109 anak dijadikan sampel. Teknik pengumpulan data yang digunakaan pada penelitian ini adalah penyebaran kuesioner (angket) dan studi pustaka (dokumentasi). Pada penelitian ini angket diisi oleh orang tua siswa.

Kuesioner keteladanan orang tua diukur dari aspek: cinta dan kasih sayang, menjadi pendengar yang baik, menciptakan suasana yang nyaman bagi anak, menghindari bersikap pilih kasih, batasan dan aturan, memberikan tanggung jawab kepada anak, membiasakan berperilaku yang benar, tidak membanding-bandingkan anak dengan orang lain, setiap orang adalah berbeda, dan menghindari pernyataan mengumpat (Yusuf, 2019), yang dijabarkan menjadi 21 item pernyataan. Perkembangan nilai moral anak diukur dari aspek: religiusitas, sosialitas, gender, keadilan, demokrasi, kejujuran, kemandirian, daya juang, tanggung jawab, dan penghargaan terhadap lingkungan alam (Zuriah, 2015), yang dijabarkan menjadi 24 item pernyataan.

Setelah data kuesioner direkap, sebelum dilakukan data olah untuk menjawab hipotesis penelitian, dilakukan terlebih dahulu uji validitas dan reliabilitas untuk memastikan bahwa item dalam kuesioner adalah valid dan kuesioner dapat diandalkan untuk pengumpulan data (reliabel). Untuk uji hipotesis digunakan analisis korelasi. Sebelum dianalisis dengan korelasi, terlebih dahulu dilakukan uji normalitas data dengan uji 
Kolmogorov-Smirnov. Apabila data terdistribusi normal, digunakan Pearson correlation (parametrik) dan apabila tidak normal digunakan Spearman Rho (non parametrik).

\section{HASIL DAN PEMBAHASAN}

\section{Uji Validitas dan Reliabilitas Kuesioner}

Untuk menjamin kevalidan dan keandalan kuesioner yang digunakan untuk pengumpulan data keteladanan orang tua dan perkembangan nilai moral anak, terlebih dahulu dilakukan uji validitas dan reliabilitas terhadap data yang telah dikumpulkan. Apabila ada item yang dinyatakan tidak valid, maka data item tersebut akan disingkirkan dan tidak diikutkan untuk analisis selanjutnya.

\section{Keteladanan Orang Tua}

Jumlah item kuesioner keteladanan orang tua adalah 21 item. Berdasarkan hasil uji validitas dengan cara mengkorelasikan antara skor item dengan total skor item melalui bantuan SPSS 24.0, diperoleh hasil seperti disajikan pada tabel 1.

Tabel 1. Hasil Uji Validitas Kuesioner Keteladan Orang Tua

\begin{tabular}{|c|c|c|c|c|}
\hline \multicolumn{5}{|c|}{ Item-Total Statistics } \\
\hline Item & $\begin{array}{l}\text { Scale Mean if } \\
\text { Item Deleted }\end{array}$ & $\begin{array}{l}\text { Scale Variance if } \\
\text { Item Deleted }\end{array}$ & $\begin{array}{c}\text { Corrected Item-Total } \\
\text { Correlation }\end{array}$ & $\begin{array}{l}\text { Cronbach's Alpha if } \\
\text { Item Deleted }\end{array}$ \\
\hline VAR00001 & 74,7798 & 34,933 & 663 & 875 \\
\hline VAR00002 & 74,7982 & 35,107 & 634 & 876 \\
\hline VAR00003 & 74,9908 & 32,546 & 738 & 870 \\
\hline VAR00004 & 74,9358 & 37,653 & 020 & 894 \\
\hline VAR00005 & 74,7615 & 34,943 & 698 & 875 \\
\hline VAR00006 & 74,8257 & 35,238 & ,564 & 877 \\
\hline VAR00007 & 74,9908 & 32,417 & 738 & 870 \\
\hline VAR00008 & 74,7339 & 36,493 & ,469 & 881 \\
\hline VAR00009 & 74,9817 & 34,870 & ,387 & ,882 \\
\hline VAR00010 & 74,7798 & 36,266 & 432 & 881 \\
\hline VAR00011 & 75,5413 & 34,788 & 313 & 887 \\
\hline VAR00012 & 74,7890 & 35,131 & 645 & 876 \\
\hline VAR00013 & 74,7706 & 34,827 & 706 & 874 \\
\hline VAR00014 & 75,3211 & 34,701 & 289 & ,890 \\
\hline VAR00015 & 74,8257 & 35,330 & ,376 & 882 \\
\hline VAR00016 & 75,0000 & 32,500 & 741 & 870 \\
\hline VAR00017 & 74,9450 & 33,941 & ,546 & 877 \\
\hline VAR00018 & 74,8807 & 33,865 & 680 & 873 \\
\hline VAR00019 & 75,0550 & 34,256 & 484 & 879 \\
\hline VAR00020 & 74,9633 & 35,517 & ,359 & 883 \\
\hline VAR00021 & 74,7248 & 35,905 &, 547 & 879 \\
\hline
\end{tabular}

Pada tabel 1 diketahui bahwa ada dua item yang tidak valid, yaitu item nomor 4 ( $\mathrm{r}=$ 0,020), dan item nomor $14(\mathrm{r}=289)$, karena kedua item tersebut memiliki Corrected Item-Total Correlation kurang dari 0,3. Hal ini sesuai pendapat Masrun dalam Sugiyono (2013) bahwa item yang mempunyai korelasi positif dengan kriterium (skor total) serta korelasi yang tinggi, menunjukkan bahwa item tersebut mempunyai validitas yang tinggi pula. Besarnya syarat minimum untuk dianggap memenuhi syarat adalah kalau $r=0,3$. Dengan demikian, data item nomor 2 dan 14 disingkirkan dan tidak diikutkan untuk analisis selanjutnya.

Berdasarkan uji reliabilitas dengan Cronbach's Alpha diperoleh hasil seperti disajikan pada tabel 2. Pada tabel 2 diketahui bahwa koefisien Cronbach's Alpha adalah 0,884. Dengan demikian kuesioner yang digunakan untuk pengumpulan data keteladanan orang tua adalah reliabel. Hal ini sesuai pendapat (Azwar, 2017) bahwa reliabilitas dinyatakan koefisien 
Hubungan Keteladanan Orang Tua dengan Perkembangan Nilai Moral Anak Usia Dini DOI: $10.31004 /$ obsesi.v6i4.2330

reliabilitas yang angkanya berada dalam rentang 0 sampai dengan 1,00. Makin tinggi koefisien reliabilitas mendekati angka 1,00 berarti semakin tinggi reliabilitas dan sebaliknya koefisien yang rendah akan semakin mendekati angka 0 . Suatu instrumen dinyatakan reliabel bila koefisien relaibilitasnya minimal 0,7 .

Tabel 2. Hasil Uji Reliabilitas Kuesioner Keteladan Orang Tua

Reliability Statistics

\begin{tabular}{rrr}
\hline Cronbach's Alpha & N of Items & \\
\hline, 884 & & 21 \\
\hline
\end{tabular}

\section{Perkembangan Nilai Moral Anak}

Jumlah item kuesioner perkembangan nilai moral anak adalah 24 item. Berdasarkan hasil uji validitas dengan cara mengkorelasikan antara skor item dengan total skor item melalui bantuan SPSS 24.0, diperoleh hasil seperti disajikan pada tabel 3.

Tabel 3. Hasil Uji Validitas Kuesioner Perkembangan Nilai Moral Anak

\section{Item-Total Statistics}

\begin{tabular}{|c|c|c|c|c|}
\hline Item & $\begin{array}{l}\text { Scale Mean if } \\
\text { Item Deleted }\end{array}$ & $\begin{array}{l}\text { Scale Variance if } \\
\text { Item Deleted }\end{array}$ & $\begin{array}{c}\text { Corrected Item-Total } \\
\text { Correlation }\end{array}$ & $\begin{array}{l}\text { Cronbach's Alpha if } \\
\text { Item Deleted }\end{array}$ \\
\hline VAR00001 & 85,7706 & 43,475 & ,587 & $\begin{array}{ll}, 887 \\
\end{array}$ \\
\hline VAR00002 & 85,6697 & 43,575 & 636 & ,886 \\
\hline VAR00003 & 86,0550 & 42,849 & 470 & 890 \\
\hline VAR00004 & 86,3578 & 42,750 & ,458 & 891 \\
\hline VAR00005 & 86,0183 & 44,148 & ,350 & ,894 \\
\hline VAR00006 & 85,6972 & 43,454 &, 554 & 887 \\
\hline VAR00007 & 85,9174 & 42,984 & 498 & ,889 \\
\hline VAR00008 & 85,8165 & 43,336 & ,581 & 887 \\
\hline VAR00009 & 86,1468 & 42,738 & ,458 & ,891 \\
\hline VAR00010 & 86,2844 & 41,539 & ,455 & ,894 \\
\hline VAR00011 & 85,7156 & 43,668 & 600 & 887 \\
\hline VAR00012 & 85,6881 & 43,420 & 641 & 886 \\
\hline VAR00013 & 86,2936 & 42,765 & 346 & 898 \\
\hline VAR00014 & 85,5505 & 46,157 & ,563 & 891 \\
\hline VAR00015 & 85,5596 & 46,212 & 483 & 891 \\
\hline VAR00016 & 85,5963 & 44,947 & ,624 & ,888 \\
\hline VAR00017 & 85,5688 & 44,877 & ,750 & 887 \\
\hline VAR00018 & 85,5872 & 44,782 & 629 & ,888 \\
\hline VAR00019 & 85,5963 & 44,799 & 660 & ,888 \\
\hline VAR00020 & 85,5780 & 44,931 & 693 & ,888 \\
\hline VAR00021 & 85,6330 & 44,734 & ,541 & ,889 \\
\hline VAR00022 & 85,5872 & 44,782 & ,629 & 888 \\
\hline VAR00023 & 85,6055 & 44,760 & ,545 & 889 \\
\hline VAR00024 & 85,9450 & 43,664 & ,448 & 890 \\
\hline
\end{tabular}

Pada tabel 3 diketahui bahwa semua item adalah valid, karena semua item memiliki Corrected Item-Total Correlation lebih besar dari 0,3. Selanjutnya berdasarkan uji reliabilitas dengan Cronbach's Alpha diperoleh hasil seperti disajikan pada tabel 4.

Tabel 4. Hasil Uji Reliabilitas Kuesioner Perkembangan Nilai Moral Anak Reliability Statistics

\begin{tabular}{rrrr}
\hline \multicolumn{2}{r}{ Cronbach's Alpha } & \multicolumn{2}{c}{ N of Items } \\
\hline &, 893 & & 24 \\
\hline
\end{tabular}


Pada tabel 4 diketahui bahwa koefisien Cronbach's Alpha adalah 0,893. Dengan demikian kuesioner yang digunakan untuk pengumpulan data perkembangan nilai moral anak adalah reliabel.

\section{Analisis Deskriptif}

\section{Keteladanan Orang Tua}

Jumlah item keteladanan orang tua yang valid dan reliabel adalah 19 item, dan masingmasing item memiliki alternatif empat respon/jawaban. Berdasarkan hasil penelitian diketahui bahwa skor terendah adalah 40 dan skor tertinggi adalah 76. Menurut Hadi (2016) untuk mencari kecenderungan tiap-tiap variabel dilakukan dengan cara membandingkan nilai rata-rata observasi dengan kurva normal. Kurva normal tersebut untuk menentukan kecenderungan masing-masing variabel dengan menggunakan skala sebagai berikut :

Golongan tinggi $=\left(\mathrm{M}_{\mathrm{i}}+1 \mathrm{SD}_{\mathrm{i}}\right)$ ke atas

Golongan sedang $=\left(\mathrm{M}_{\mathrm{i}}-1 \mathrm{SD}_{\mathrm{i}}\right) \mathrm{s} / \mathrm{d}\left(\mathrm{M}_{\mathrm{i}}+\mathrm{SD}_{\mathrm{i}}\right)$

Golongan rendah $=\left(\mathrm{M}_{\mathrm{i}}-1 \mathrm{SD}_{\mathrm{i}}\right)$ ke bawah

di mana :

$\mathrm{M}_{\mathrm{i}}=1 / 2($ skor tertinggi + skor terendah)

$\mathrm{SD}_{\mathrm{i}}=1 / 6$ (skor tertinggi - skor terendah)

Berdasarkan rumus di atas, dapat dihitung:

$\mathrm{M}_{\mathrm{i}}=1 / 2(76+40)=58$

$\mathrm{SD}_{\mathrm{i}}=1 / 6(76-40)=6$

Jadi:

Golongan tinggi $=\left(\mathrm{M}_{\mathrm{i}}+1 \mathrm{SD}_{\mathrm{i}}\right)$ ke atas $=(58+6)$ ke atas $=64 \mathrm{~s} / \mathrm{d} 76$

Golongan sedang $=\left(\mathrm{M}_{\mathrm{i}}-1 \mathrm{SD}_{\mathrm{i}}\right) \mathrm{s} / \mathrm{d}\left(\mathrm{M}_{\mathrm{i}}+\mathrm{SD}_{\mathrm{i}}\right)=(58-6) \mathrm{s} / \mathrm{d}(58+6)=52 \mathrm{~s} / \mathrm{d} 63$

Golongan rendah $=\left(\mathrm{M}_{\mathrm{i}}-1 \mathrm{SD}_{\mathrm{i}}\right)$ ke bawah $=(58-6) \mathrm{ke}$ bawah $=40 \mathrm{~s} / \mathrm{d} 51$

Skor over protective orang tua dapat dikelompokkan menjadi 3 kelas/kelompok, yaitu rendah, sedang, dan tinggi seperti terlihat pada tabel 5 dan gambar 2.

Tabel 5. Kategori Skor Keteladanan Orang Tua

\begin{tabular}{cccc}
\hline Skor & Kategori & Jumlah & Persentase \\
\hline $40-51$ & Rendah & 3 & 2,75 \\
$52-63$ & Sedang & 8 & 7,34 \\
$64-76$ & Tinggi & 98 & 89,91 \\
\hline Jumlah & & 109 & 100,00 \\
\hline
\end{tabular}

\section{Kategori Skor Keteladanan Orang tua}

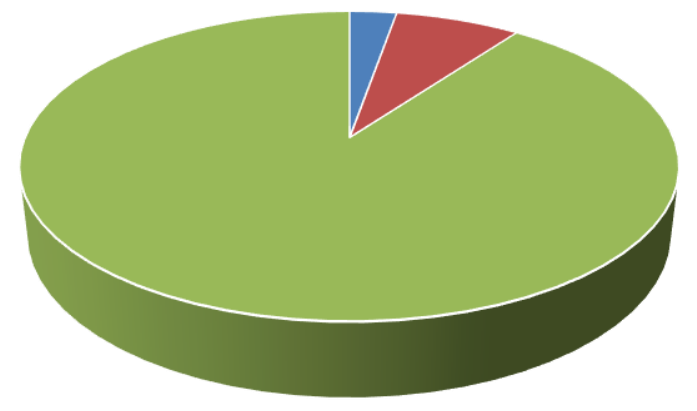

- 40 - 51 Rendah $=52-63$ Sedang $=64-76$ Tinggi

Gambar 2. Kategori Skor Keteladanan Orang Tua 
Pada tabel 5 dan gambar 2 diketahui bahwa dari 109 responden terdapat 3 orang tua $(2,75 \%)$ yang kurang memberikan perilaku keteladanan kepada anaknya, 8 orang tua $(7,34 \%)$ cukup memberikan perilaku keteladanan kepada anaknya, dan 98 orang tua $(89,91 \%)$ seringkali memberikan perilaku keteladanan yang baik kepada anaknya. Dari temuan ini dapat dikatakan bahwa sebagian besar orang tua seringkali memberikan perilaku keteladanan yang baik kepada anaknya.

\section{Perkembangan Nilai Moral Anak}

Jumlah item yang valid dan reliabel untuk mengukur perkembangan nilai moral anak sebanyak 24 item. Berdasarkan hasil penelitian diketahui bahwa skor terendah adalah 54 dan skor tertinggi adalah 96. Berdasarkan rumus Hadi (2016), maka skor selanjutnya dapat dikelompokkan seperti terlihat pada tabel 6 dan gambar 3 .

Tabel 6. Kategori Skor Perkembangan Nilai Moral Anak

\begin{tabular}{cccc}
\hline Skor & Kategori & Jumlah & Persentase \\
\hline $54-68$ & Rendah & 1 & 0,92 \\
$69-82$ & Sedang & 6 & 5,50 \\
$83-96$ & Tinggi & 102 & 93,58 \\
\hline Jumlah & & 109 & 100,00 \\
\hline
\end{tabular}

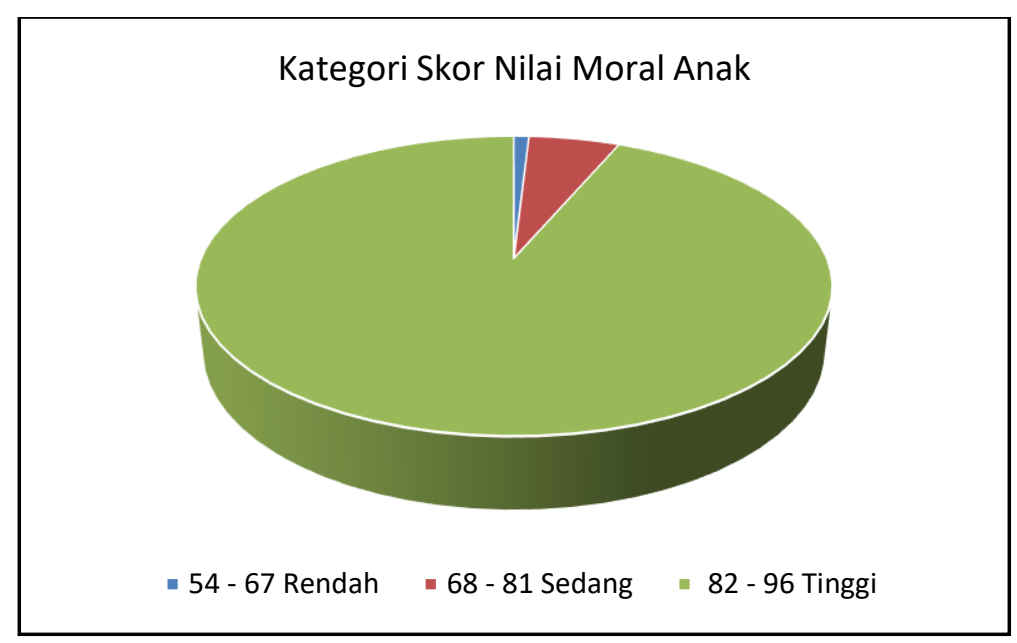

Gambar 3. Kategori Skor Perkembangan Nilai Moral Anak

Pada tabel 6 dan gambar 3 diketahui bahwa dari 109 responden terdapat 1 anak $(0,92 \%)$ menunjukkan perkembangan nilai moral yang kurang baik, 6 anak $(5,50 \%)$ menunjukkan perkembangan nilai moral yang cukup baik, dan 102 anak (93,58\%) menunjukkan perkembangan nilai moral yang sangat baik. Dari temuan ini dapat dikatakan bahwa sebagian besar anak sudah menunjukkan perkembangan nilai moral yang sangat baik.

\section{Analisis Hubungan Keteladanan Orang Tua dengan Perkembangan Nilai Moral Anak Uji Normalitas Data}

Berdasarkan hasil uji normalitas data dengan Kolmogorov-Smirnov, diperoleh hasil seperti tabel 7. Pada tabel 7 diketahui bahwa nilai signifikansi variabel keteladanan orang tua adalah 0,000 $<0,05$ dan perkembangan nilai moral anak adalah 0,000 $<0,05$. Berarti kedua data tidak terdistribusi normal. Oleh karena itu, uji korelasi menggunakan Spearman Rho (uji non parametrik). Berdasarkan hasil uji Spearman Rho hasilnya disajikan pada tabel 8. Pada tabel 8 diketahui bahwa koefisien korelasi Spearman Rho sebesar 0,648 dengan signifikansi 0,000 < 0,05 . Dengan demikian, variabel keteladanan orang tua dengan perkembangan nilai moral anak memiliki hubungan yang kuat dan signifikan. Hal ini mengindikasikan bahwa semakin 
sering orang tua memberikan perilaku keteladanan kepada anaknya, maka perkembangan nilai moral anak semakin meningkat.

Tabel 7. Hasil Uji Normalitas Data One-Sample Kolmogorov-Smirnov Test

\begin{tabular}{llr|r}
\hline & & Keteladanan & Nilai_Moral \\
\hline $\mathrm{N}$ & & 109 & 109 \\
\hline Normal Parameters & & & \\
& Mean & 71,0642 & 90,1101 \\
\cline { 2 - 4 } & Std. Deviation & 5,88041 & 5,59653 \\
\hline \multirow{2}{*}{ Most Extreme Differences } & Absolute &, 201 &, 169 \\
\cline { 2 - 4 } & Positive &, 201 &, 146 \\
\cline { 2 - 4 } & Negative & -193 &,- 169 \\
\hline Test Statistic & &, 201 &, 169 \\
\hline Asymp. Sig. (2-tailed) &, $000^{c}$ &, $000^{c}$ \\
\hline
\end{tabular}

a. Test distribution is Normal.

b. Calculated from data.

c. Lilliefors Significance Correction.

Tabel 8. Hasil Uji Korelasi Spearman Rho Correlations

\begin{tabular}{llr|r}
\hline & & Keteladanan & Nilai_Moral \\
\hline Spearman's rho Keteladanan & Correlation Coefficient & 1,000 &, $648^{\text {** }}$ \\
\cline { 3 - 5 } & Sig. (2-tailed) &. &, 000 \\
\cline { 2 - 5 } & $\mathrm{N}$ & 109 & 109 \\
\cline { 2 - 5 } & Nilai_Moral &, $648^{* *}$ & 1,000 \\
\cline { 2 - 5 } & Correlation Coefficient &, 000 &. \\
\cline { 2 - 5 } & Sig. (2-tailed) & 109 & 109 \\
\cline { 2 - 5 } & $\mathrm{N}$ & &
\end{tabular}

**. Correlation is significant at the 0.01 level (2-tailed).

\section{Pembahasan}

Sebagian besar orang tua seringkali memberikan perilaku keteladanan yang baik kepada anaknya, dan sebagian besar anak sudah menunjukkan perkembangan nilai moral yang sangat baik. Selanjutnya berdasarkan analisis korelasi, diketahui bahwa keteladanan orang tua dengan perkembangan nilai moral anak memiliki hubungan yang kuat dan signifikan. Hal ini mengindikasikan bahwa semakin sering orang tua memberikan perilaku keteladanan kepada anaknya, maka perkembangan nilai moral anak semakin meningkat.

Berkaitan dengan hasil penelitian di atas, maka orang tua memiliki peran penting di dalam membentuk kepribadian anak usia dini. Orang tua dapat memberikan teladan yang baik bagi perilaku anaknya, karena anak yang masih kecil pada umumnya akan menirukan perilaku orang tuanya. Zakiah Daradjat dalam Reksiana (2019) berpendapat bahwa keluarga merupakan wadah pertama yang memiliki peran paling sentral bagi pertumbuhan dan perkembangan seorang anak. Jika lingkungan keluarga baik, anak akan tumbuh dengan baik pula. Sebaliknya, jika lingkungan tidak baik, perkembangan anak juga akan terhambat. Jelasnya, orang tualah yang memiliki pengaruh yang signifikan dalam memberikan pendidikan karakter. Penelitian Agustina et al. (2021) menyimpulkan bahwa keterlibatan orang tua dalam mendampingi anak belajar di rumah, menjadikan orang tua memiliki dua peran yaitu peran sebagai orang tua yang memberikan pengasuhan dan juga peran sebagai guru. Sutiyani et al. (2021) menambahkan bahwa keluarga merupakan lingkungan pendidikan pertama yang menanamankan, menguatkan serta mengembangkan karakter dasar seorang anak yang telah dibentuk di dalam keluarga.

Nasrudin dalam Reksiana (2019) menambahkan bahwa keluarga sebagai model peranan. Dalam hal ini orang tua berperan dalam berbagai macam nilai kehidupan yang dapat diterima dan diaplikasikan oleh anak. Keteladanan orang tua merupakan faktor yang 
entitas bagi anak. Seperti berbicara, cara berpakaian, cara bertindak, dan lain-lain. dengan demikian, orang tua tetap menjadi pedoman bagi pembentukan nilai-nilai pada pola tingkah anak. Hasil penelitian Juanda (2019) menyimpulkan bahwa pengasuhan anak dapat dilakukan dengan cara:: melihat anak itu sebagai pribadi; keikutsertaan empati dengan anak; sikap interpretatif menghormati anak ungkapan-ungkapan dan arti kehidupan dunia; membimbing anak dengan cara yang sensitif; prawatan dini dan pendidikan adalah proses dialogis antara anak dan pengasuh. Vasilyevaa dan Shcherbakovb (2016) dalam Rohita (2021) menambahkan bahwa orangtua adalah pembentuk kepribadian anak, sehingga orangtua harus dapat menjadi teladan bagi anak-anaknya, terlebih pada masa anak memasuki usia prasekolah.

Pada dasarnya suri teladan yang baik memiliki dampak yang besar pada kepribadian anak (Darajat, 2015). Tidak mungkin anak belajar menahan emosi, jika ia melihat orang tuanya marah-marah dan emosional. Seperti halnya tidak mungkin pula anak belajar kasih sayang, kalau ia melihat orang tuanya bersikap keras. Anak akan tumbuh dnegn kebaikan, terdidik dalam akhlak terpuji, jika ia mendapatkan teladan dari kedua orang tuanya. Sebaliknya ia akan menyimpang dari kebaikan dan biasa berbuat dosa, jika sering melihat orang tuanya memberi contoh perbuatan dosa (Suwaid, 2010).

Anak umumnya meniru perilaku yang ditunjukkan oleh orang tuanya, maka dalam mendidik anak faktor keteladan perilaku yang baik yang ditunjukkan oleh orang tua sangat berpengaruh terhadap perkembangan budi pekerti anak. Menurut psikolog Lina Erliana (2011) dalam Wibowo (2017) anak adalah sang peniru ulang. Semua aktivitas orang tua selalu dipantau anak dan dijadikan model yang ingin dicapainya. Pendek kata, semua prilaku orang tua termasuk kebiasaan buruk yang dilakukan akan mudah ditiru oleh anak.

Hasil penelitian Hakim et al. (2018) dengan judul “Hubungan Keteladanan Orang Tua dengan Adab Siswa Tingkat Sekolah Dasar di Bogor" menyimpulkan bahwa ada korelasi antara keteladanan orang tua dengan adab siswa. Penelitian Mulyati et al. (2020) dengan judul "Pengaruh Keteladanan Guru dan Orang Tua terhadap Sikap Kejujuran Siswa SMK Klaten, Jawa Tengah" menyimpulkan bahwa: (1) keteladanan guru berpengaruh positif terhadap sikap kejujuran siswa; (2) keteladanan orang tua berpengaruh positif terhadap sikap kejujuran siswa. Penelitian Utami \& Prasetyo (2021) juga menyimpulkan bahwa terdapat hubungan pengasuhan yang diberikan orang tua terhadap pembentukan karakter disiplin anak.

Hasil penelitian Suhono \& Utama (2017) dengan judul “Keteladanan Orang Tua dan Guru dalam Pertumbuhan dan Perkembangan Anak Usia Dini" menunjukan bahwa konsep keteladanan Abdullah Nashih Ulwan adalah metode influentif yang paling meyakinkan keberhasilannya dalam mempersiapkan dan membentuk anak untuk membentuk pribadi yang bermoral, sosial, dan spiritual, dengan contoh yang terbaik dalam pandangan anak, yang akan ditiru dalam tindak dan tanduknya, dan tata santunnya, disadari ataupun tidak, bahkan tercetak dalam jiwa dan perasaan anak, tentang gambaran pendidik tersebut, baik dalam ucapan ataupun perbuatan. Oleh karena itu sebagai seorang pendidik harus memiliki figur keteladanan yang baik, sesuai kriteria dari ajaran yang telah diberikan oleh Islam tentang akhlakul karimah.

Hasil penelitian Kabiba et al. (2017) dengan judul “Keteladanan Orang Tua dalam Menanamkan Nilai Etika Pada Anak" menyimpulkan bahwa bentuk keteladanan orang tua tersebut berupa: mengajarkan dan membimbing anaknya tidak hanya dengan aturan tetapi juga harus disertai contoh nyata, memperhatikan setiap kesempatan untuk memberikan pujian atau penghargaan secara wajar, memberikan pemahaman tentang pentingnya kaidahkaidah, nilai etika serta manfaatnya bagi masa depan anak dan memberikan tanggung jawab kepada anak agar anak lebih mampu mempertanggung jawabkan tindakan-tindakannya.

Hasil penelitian Kusdi (2018) yang berjudul “ Peranan Pola Asuh Orang Tua dalam Pembentukan Karakter Anak" menyimpulkan bahwa pendidikan dalam keluarga merupakan pendidikan awal bagi anak karena pertama kalinya mereka mengenal dunia 
terlahir dalam lingkungan keluarga dan dididik oleh orang tua. Sehingga pengalaman masa anak-anak merupakan faktor yang sangat penting bagi perkembangan selanjutnya, keteladanan orang tua dalam tindakan sehari-hari akan menjadi wahana pendidikan moral bagi anak, membentuk anak sebagai makhluk sosial, religius, untuk menciptakan kondisi yang dapat menumbuh kembangkan inisiatif dan kreativitas anak. Dengan demikian, tidak dapat dipungkiri bahwa peran keluarga sangat besar sebagai penentu terbentuknya moral manusia-manusia yang dilahirkan. Hasil penelitian Wahyuni \& Purnama (2021) menyimpulkan bahwa nilai-nilai dari karakter tersebut adalah mengenal agama yang dianut, mengerjakan ibadah, berperilaku jujur, penolong, hormat, sportif, menjaga kebersihan diri dan lingkungan, mengetahui hari besar agama, menghormati (toleransi).

Hasil penelitian Abdurrahman (2018) dengan judul "Upaya Meningkatkan Perkembangan Nilai Agama dan Moral Melalui Metode Keteladanan Pada Anak Usia Dini" menyimpulkan bahwa usia dini merupakan masa golden age atau masa keemasan, yang mana anak akan mengalami pertumbuhan dan perkembangan yang sangat pesat dan tidak tergantikan pada masa mendatang. Dimana perlunya sebuah keteladanan orang tua dalam mengembangkan berbagai aspek, terutamanya aspek sosial emosional, dimana orang tua disini berperan sangat penting sebagai teladan yang sangat berpengaruh bagi perkembangan dan pertumbuhan anak dalam berbagai aspek dalam kehidupan. Sosial emosional sangat penting dalam kehidupan anak karena sosial emosional tersebut merupakan sikap dan tingkah laku anak, bagaimana anak bertingkah laku kepada teman, keluarga maupun guru, jadi peran orang tua sebagai teladan untuk anak sangat jelas, dimana jika orang tua jika memberi teladan yang baik sekalipun buruk kepada anak itu akan berdampak pada sosial dan emosional anak di masa mendatang. Jadi tentu saja keteladanan yang baiklah yang harus diteladani orang tua kepada anak.

Budiyono \& Harmawati (2017) dalam tulisannya berjudul "Penguatan Pendidikan Karakter Melalui Nilai-Nilai Keteladanan Guru dan Orang Tua pada Siswa Sekolah Dasar" menyimpulkan bahwa keteladanan merupakan salah satu hal yang penting dalam pendidikan. Pendidikan karakter dapat dilakukan melalui pembelajaran baik pada mata pelajaran maupun kegiatan ekstrakurikuler, kemudian dapat juga melalui keteladanan, pembiasaan dan pengulangan serta pembinaan.

\section{SIMPULAN}

Sebagian besar orang tua seringkali memberikan perilaku keteladanan yang baik kepada anaknya. Adanya perilaku keteladanan yang baik dari orang tuanya tersebut, maka anak menunjukkan perkembangan nilai moral yang sangat baik. Selanjutnya berdasarkan analisis korelasi, diketahui bahwa keteladanan orang tua dengan perkembangan nilai moral anak memiliki hubungan yang kuat dan signifikan. Artinya, semakin sering orang tua memberikan perilaku keteladanan kepada anaknya, maka perkembangan nilai moral anak semakin meningkat. Oleh karena itu, dalam mendidik anaknya, orang tua tidak hanya cukup dengan perintah atau ucapan saja, tetapi harus memberikan contoh perilaku yang baik bagi anaknya, dan dapat dijadikan figur yang pantas diteladani.

\section{UCAPAN TERIMA KASIH}

Peneliti mengucapkan terima kasih kepada kepala sekolah, guru dan orang tua anak yang telah berpartisipasi aktif membantu pengisian kuesioner.

\section{DAFTAR PUSTAKA}

Abdurrahman. (2018). Upaya meningkatkan perkembangan nilai agama dan moral melalui metode keteladanan pada anak usia dini. Jurnal Penelitian Keislaman, 14(2), 101-107. https://doi.org/10.20414/jpk.v14i2.698 
Agustina, M. R., Dhieni, N., Anak, P., Dini, U., \& Timur, J. (2021). Keterlibatan Orang Tua dalam Mendampingi Anak Usia Dini Belajar dari Rumah di Masa Pandemi Covid-. 5(2), 2146-2157. https:// doi.org/10.31004/obsesi.v5i2.1160

Amin, M., Kristiana, D., \& Fadlillah, M. (2021). Jurnal Obsesi : Jurnal Pendidikan Anak Usia Dini Pengaruh Kelekatan Aman Anak pada Ibu terhadap Kemandirian Anak Usia 5-6 Tahun Abstrak. 5(1), 127-134. https://doi.org/10.31004/obsesi.v5i1.504

Azwar, S. (2017). Validitas dan reliabilitas. Pustaka Pelajar.

Budiyono, \& Harmawati, Y. (2017). Penguatan pendidikan karakter melalui nilai-nilai keteladanan guru dan orang tua pada siswa sekolah dasar. Prosiding Seminar Nasional PPKN III, 1-10.

Darajat, Z. (2015). Pengajaran agama islam. Bumi Aksara.

Hadi, S. (2016). Statistik. ANDI Yogyakarta.

Hakim, L. N., Muhyani, \& Supraha, W. (2018). Hubungan keteladanan orang tua dengan adab siswa tingkat sekolah dasar di Bogor. Tawazun: Jurnal Pendidikan Islam, 11(2), 263281. https:// doi.org/10.32832/tawazun.v11i2.1581

Jeti, L., Manan, Risman, K., \& Edison. (2021). Jurnal Obsesi : Jurnal Pendidikan Anak Usia Dini Application of Philosophy Values of Bhinci-Bhinciki Kuli in Early Childhood at Wolio Community Abstrak. 5(1), 530-537. https://doi.org/10.31004/obsesi.v5i1.643

Juanda. (2019). Jurnal Obsesi : Jurnal Pendidikan Anak Usia Dini Pendidikan Karakter Anak Usia Dini melalui Sastra Klasik Fabel Versi Daring. 3(1), 39-54. https://doi.org/10.31004/obsesi.v3i1.126

Kabiba, Pahenra, \& Juli, B. (2017). Keteladanan orang tua dalam menanamkan nilai etika pada anak. Didaktis: Jurnal Pendidikan Dan Ilmu Pengetahuan, 17(1), 10-22.

Kurniati, E., Kusumanita, D., Alfaeni, N., \& Andriani, F. (2021). Jurnal Obsesi : Jurnal Pendidikan Anak Usia Dini Analisis Peran Orang Tua dalam Mendampingi Anak di Masa Abstrak. 5(1), 241-256. https:// doi.org/10.31004/obsesi.v5i1.541

Kusdi, S. S. (2018). Peranan pola asuh orang tua dalam pembentukan karakter anak. AlUswah: Jurnal Riset Dan Kajian Pendidikan Agama Islam, 1(2), 100-111. https://doi.org/10.24014/au.v1i2.6253

Mukarromah, T. T., Hafidah, R., \& Nurjanah, N. E. (2021). Jurnal Obsesi : Jurnal Pendidikan Anak Usia Dini Kultur Pengasuhan Keluarga terhadap Perkembangan Moral Anak Usia Dini Abstrak. 5(1), 395-403. https://doi.org/10.31004/obsesi.v5i1.550

Mulyati, Hidayati, M., \& Hariyanto, M. (2020). Pengaruh keteladanan guru dan orang tua terhadap sikap kejujuran siswa SMK Klaten, Jawa Tengah. Cendekia, 14(2), 183-195.

Purnama, S., \& Hidayati, L. (2020). Jurnal Obsesi : Jurnal Pendidikan Anak Usia Dini Pengasuhan Anak Usia Dini dalam Hikayat Indraputra. 4(2), 520-542. https://doi.org/10.31004/obsesi.v4i2.391

Putri, A. L. D., Yetti, E., \& Hartati, S. (2020). Jurnal Obsesi : Jurnal Pendidikan Anak Usia Dini Pengaruh Keterlibatan Orangtua dan Regulasi Diri terhadap Perilaku Bullying Anak Usia Dini Abstrak. 4(1), 715-732. https://doi.org/10.31004/obsesi.v4i2.438

Ramdhani, S., Yuliastri, N. A., Sari, S. D., Hasriah, S., Hamzanwadi, P. F. U., \& Adniyah, T. K. U. (2019). Jurnal Obsesi : Jurnal Pendidikan Anak Usia Dini Penanaman Nilai-Nilai Karakter Melalui Kegiatan Storytelling dengan Menggunakan Cerita Rakyat Sasak pada Anak Usia Dini. 3(1), 153-160. https://doi.org/10.31004/obsesi.v3i1.108

Reksiana. (2019). Grand design of educational institutions in character education. Al - Iltizam, 4(1), 1-24. https://doi.org/10.33477/alt.v4i1.780

Rohita. (2021). Jurnal Obsesi : Jurnal Pendidikan Anak Usia Dini Pengenalan Covid-19 pada Anak Usia Prasekolah : Analisis pada Pelaksanaan Peran Orangtua di Rumah Abstrak. 5(1), 315-326. https:// doi.org/10.31004/obsesi.v5i1.528

Sofia, A., Nopiana, \& Suryadi. (2021). Jurnal Obsesi : Jurnal Pendidikan Anak Usia Dini Faktor Penunjang dan Penghambat dalam Pengembangan Kecerdasan Moral Anak Usia Dini 5-6 Tahun Abstrak. 5(1), 599-610. https://doi.org/10.31004/obsesi.v5i1.467 
Sugiyono. (2013). Metode Penelitian Pendidikan. Alfabeta.

Suhono, \& Utama, F. (2017). Keteladanan orang tua dan guru dalam pertumbuhan dan perkembangan anak usia dini (perspektif abdullah nashih ulwan kajian kitab tarbiyyah $\begin{array}{llll}\text { al-aulad fi } & \text { al-islam). }\end{array}$ https:// doi.org/10.32332/elementary.v3i2.833

Sutanto, A. V., \& Andriyani, A. (2019). Positif parenting: membangun karakter positf anak. Pustaka Baru.

Sutiyani, F., Adi, T. T., \& Meilanie, R. S. M. (2021). Nilai-Nilai Pendidikan Karakter pada Film Adit dan Sopo Jarwo Ditinjau dari Aspek Pedagogik. 5(2), 2201-2210. https://doi.org/10.31004/obsesi.v5i2.1133

Suwaid, M. N. A. H. (2010). Prophetic parenting cara nabi mendidik anak. Pro-U Media.

Towoliu, I. D., \& Hartati, S. (2021). Jurnal Obsesi: Jurnal Pendidikan Anak Usia Dini Pendidikan Karakter Berbasis Islam melalui Program Cinta Rosul pada Anak Taman Kanak-Kanak Abstrak. 5(1), 521-529. https://doi.org/10.31004/obsesi.v5i1.618

Ulfah, M. (2020). Jurnal Obsesi : Jurnal Pendidikan Anak Usia Dini Pendekatan Holistik Integratif Berbasis Penguatan Keluarga pada Pendidikan Anak Usia Dini Full Day Abstrak. 4(1), 10-19. https:// doi.org/10.31004/obsesi.v4i1.255

Utami, F., \& Prasetyo, I. (2021). Pengasuhan Keluarga terhadap Perkembangan Karakter Disiplin Anak Usia Dini. 5(2), 1777-1786. https://doi.org/10.31004/obsesi.v5i2.985

Wahyuni, S., \& Purnama, S. (2021). Jurnal Obsesi : Jurnal Pendidikan Anak Usia Dini Pengembangan Religiusitas m elalui Metode Kisah Qur ' ani di Abstrak. 5(1), 103-116. https:// doi.org/10.31004/obsesi.v5i1.523

Wibowo, A. (2017). Pendidikan karakter usia dini (strategi membangun karakter di usia dini). Pustaka Pelajar.

Yusuf, S. (2019). Psikologi Perkembangan Anak \& Remaja (R. Rosdakarya (ed.)).

Zuriah, N. (2015). Pendidikan moral \& budi pekerti dalam perspektif perubahan. Bumi Aksara. 